\title{
A Quiet Revolution: STV and the Scottish Council Elections of 2007
}

\section{David Denver}

\author{
Hugh Bochel
}

As in 1999 and 2003, the 2007 elections for Scottish local councils were held on the same day (May $3^{\text {rd }}$ ) as the Scottish Parliament elections. This was despite the fact that in the interim the Arbuthnott Commission, set up to report on elections in Scotland, had firmly recommended the 'decoupling' of the two sets of elections (Commission on Boundary Differences and Voting Systems, 2006, pp. 48-51). As a result, in terms of media attention the local elections were once again largely overshadowed by the Scottish Parliament elections both during the campaign and in the reporting of results. This is a pity because for the first time in a public election in mainland Britain, the Scottish local elections were fought using the Single Transferable Vote (STV) electoral system. The new system had a variety of effects barely-noticed by the media - there was, indeed, a quiet revolution - that will resonate in Scottish local government and politics for a long time to come.

\section{Preparations for STV}

The STV electoral system for council elections was introduced by the Local Governance (Scotland) Act passed by the Scottish Parliament in 2004. The system requires voters to rank candidates in order of preference and is intended to produce outcomes in terms of seats that are more proportional to votes than the traditional first-past-the-post system. Understandably, many in the Labour party were hostile to the move since the party was bound to lose seats and control of councils under the new system. In such circumstances switching to STV might appear a selfless act on the part of the Labour leadership in Scotland. Of course it was no such thing. STV for local government was the 'pound of flesh' that the Liberal Democrats extracted as the price of their continuing the coalition arrangement with Labour in the Scottish Executive after the 2003 Scottish Parliament elections.

STV requires multi-member electoral districts and so implementing the system required a complete redrawing of ward boundaries to create new wards that would elect either three or four councillors. This was undertaken by the Scottish Local Government Boundary Commission and the final outcome was a reduction from 1,222 single member wards to 353 multi-member wards, 190 electing three councillors and 163 electing four with the total number of councillors remaining at 1,222. (For details of the work of the Boundary Commission see http://www.lgbc-scotland.gov).

In addition, it was the introduction of STV that was the main impetus behind another innovation with respect to the elections - the decision to count votes electronically. Counting votes and determining results manually under STV can be an arduous and lengthy process and so a firm was engaged to provide the hardware and software required for computerised counting. Early trials were not entirely encouraging - in at least one demonstration the systems crashed. There was also much criticism of computerised counting on election night and immediately after. Most of this was focussed on the counting of Scottish Parliament election votes, however. For the local elections, the system worked fairly smoothly in most cases and initial results were announced reasonably quickly after counting began. 
In what follows we look at how parties and voters reacted to STV and then consider the impact of the new system on local government in Scotland.

\section{The Parties: Candidates}

Table 1 shows the numbers of candidates who contested the 2007 elections as compared with the two previous rounds of elections. In 2003 a new record was set for the number of candidates put forward - almost 4,200 for the 1,222 council seats at stake. In 2007, however, although the number of available council seats remained the same, the number of candidates fell to 2,606. This was certainly due to the introduction of STV but had two slightly different immediate causes. In the first place, since an individual party is unlikely to win all the seats at stake in a ward under STV - the whole point being to produce a more proportional outcome - the major parties clearly calculated that their chances of winning seats would be improved if they nominated only as many candidates in a ward as they thought could win seats. This would avoid first preference votes being divided among too many candidates. There were only two wards (in East Ayrshire and North Lanarkshire) in which a party (Labour) put forward a full slate of candidates. Secondly, in areas of weakness a party could 'show the flag' or force a ward contest with just one candidate where previously they would have had to find three or four. Before the change 1,222 candidates were required to contest every ward; under the new system 353 sufficed. For these reasons, as the table shows, there were large declines in the numbers of candidates put forward by the major parties, with the SNP leading the way $(-533)$. This left Labour as the party with the largest number of local election candidates for the first time under the current local government system.

Such calculations do not apply in the same way to Independents, however, who appear to have perceived STV as an opportunity rather than as a reason for strategic withdrawals. The number of Independent candidates increased $(+63)$ and this was not confined to areas where almost all candidates stand as Independents - the islands councils. Of the 29 mainland councils there was an increase in Independent candidatures in 19. Minor parties, apart from the Scottish Socialist Party (SSP) which had been affected by a split, also increased their participation. There was a veritable explosion in Green candidates (+99) while Solidarity (a breakaway from the SSP) entered the fray for the first time with 83 candidates. Among the 'others', the Scottish Unionist Party ('Proudly Scottish, Proudly British') led with 18 candidates, followed by UKIP with 10, the BNP with 7 and local hospital action groups also with 7.

Table 1

Number of Candidates in Council Elections 1999-2007

$\begin{array}{lrrrr} & & & & \text { Change } \\ & 1999 & 2003 & 2007 & 2003-7 \\ \text { Con } & 728 & 798 & 379 & -419 \\ \text { Lab } & 980 & 920 & 521 & -399 \\ \text { Lib Dem } & 607 & 676 & 331 & -345 \\ \text { SNP } & 1057 & 969 & 436 & -533 \\ \text { Ind } & 404 & 488 & 551 & +63 \\ \text { SSP } & 100 & 315 & 126 & -189 \\ \text { Solidarity } & - & - & 83 & +83 \\ \text { Green } & - & 1 & 100 & +99\end{array}$


Others

It is claimed by proponents that STV is a more 'democratic' electoral system than first-pastthe-post. If the health of local democracy is measured by the willingness of candidates to come forward, however, then its introduction appears to have had an unfortunate - and probably unforeseen - effect. Parties are the main recruiters of candidates and the tactical calculations of the parties in the light of STV meant that they did not want to recruit as many as before. As a result, some 1,600 fewer people were involved in the elections as candidates than had been the case in 2003. On the other hand, for reasons already discussed not a single ward was uncontested for the first time ever in Scottish local elections.

Two further consequences of STV for candidatures are not apparent from the data in Table 1. Firstly, there was a sharp decline in the proportion of incumbent councillors seeking reelection. In 2003, 84\% of incumbent councillors defended their seats; in 2007 only $62 \%$ fought a seat under the new arrangements. Although some may have been put off by the larger wards and the new electoral system, the fact that parties (especially the Labour party which was by far the biggest party in Scottish local government after 2003) did not want to put forward a full slate of candidates, even in wards where they previously held all the firstpast-the-post seats, clearly meant that fewer incumbents would stand. It should be noted, however, that incumbents may have found it easier than usual to retire since the Scottish Parliament authorised the payment of 'golden goodbyes' (cash payments for service given) to councillors who stood down.

Secondly, as Table 2 shows, there was a clear decline in the proportion of candidates who are female and this occurred among all of the major parties. This reversed a long-term trend in Scottish local elections. It is sometimes suggested that proportional electoral systems encourage more women candidates since parties might deem it politic to put forward, say, one woman and one man in a ward. It appears, however, that providing a choice of male and female candidates to the voters did not play any significant part in the selection of major party candidates. Rather, it seems that in a situation where the parties were looking for fewer candidates and in the scramble to be selected women appear to have lost out. In some parties, however, such as the Conservatives, and in some areas, it may have been that in the past women were willing to act as sacrificial lambs in hopeless wards, or were less likely to selected in winnable wards. Under STV, neither of these possibilities was as likely, and the impact of this is reflected in the figures showing the proportion of women councillors. This clearly increased in the case of the Conservatives and overall was unchanged at $21.8 \%$. The greatly reduced number of women candidates won as many council seats as before.

Table 2

Percentage of Women Candidates and Councillors 1999-2007

\begin{tabular}{lcccccc} 
& \multicolumn{3}{c}{ Candidates } & \multicolumn{3}{c}{ Councillors } \\
& 1999 & 2003 & 2007 & 1999 & 2003 & 2007 \\
Con & 31.0 & 32.3 & 25.3 & 27.8 & 22.8 & 25.9 \\
Lab & 23.5 & 25.9 & 20.3 & 21.6 & 20.0 & 17.5 \\
Lib Dem & 37.6 & 37.4 & 31.4 & 32.7 & 32.6 & 30.1
\end{tabular}




$\begin{array}{lrrrrrr}\text { SNP } & 24.9 & 25.0 & 22.0 & 24.5 & 24.9 & 22.3 \\ \text { Ind } & 17.4 & 16.0 & 15.4 & 15.7 & 15.2 & 16.6 \\ \text { SSP } & 27.0 & 27.9 & 28.6 & 0.0 & 0.0 & 0.0 \\ \text { Solidarity } & - & - & 25.3 & - & - & 100 \\ \text { Green } & - & - & 39.0 & & & 50.0 \\ \text { Others } & 18.2 & 13.8 & 15.2 & 8.3 & 0.0 & 20.0 \\ \text { All } & 26.8 & 27.7 & 22.8 & 23.0 & 21.8 & 21.8\end{array}$

\section{The Voters: Rejected Ballots and Turnout}

Voting in a first-past-the-post election is easy and familiar - all that a voter has to do is mark an ' $\mathrm{X}$ ' opposite the name of the preferred candidate. Nonetheless, there are always some ballots that are rejected or regarded as 'spoilt' for one reason or another - some are deliberately spoiled, for example, because there is no candidate representing the party supported by the voter, others are accidentally spoiled. Voting under STV is unfamiliar and more complicated - the voter has to list candidates in order of preference - and, despite the fact that the Electoral Commission and others conducted public information campaigns on how to vote, we would expect there to be more incorrectly completed ballots. Table 3 shows the number of rejected ballots in 2007 as compared with the previous two rounds of elections and these as a percentage of all ballots. As can be seen, there was indeed an increase in rejected ballots (although to nothing like the extent that occurred in the Parliament elections). Given the unfamiliarity of STV for most people, $1.83 \%$ of ballots rejected seems not an unreasonable figure. The vast majority of voters were clearly able to handle preferential voting. For comparison, STV has been used in Ireland since the 1920s and in the 2007 Irish general election a mean of $0.99 \%$ of ballots were rejected in eleven Dublin constituencies (electionsireland.org).

Table 3

Rejected Ballots in Council Elections, 1999-2007

$\begin{array}{lrrr} & 1999 & 2003 & 2007 \\ \text { Number } & & & \\ \% & 13,597 & 14,579 & 38,351 \\ & 0.59 & 0.77 & 1.83\end{array}$

There was relatively little variation across councils in the proportion of STV ballots rejected. It ranged from $1.11 \%$ (in East Dunbartonshire) to $2.77 \%$ (in, oddly enough, West Dunbartonshire). Around a mean score of 1.82 the standard deviation was 0.42 .

Further evidence that the new method of voting did not trouble voters unduly comes from a post-election survey conducted under the auspices of the Scottish Election Study (SES). ${ }^{1}$ Respondents were asked how difficult they had found completing the ballot papers for the Scottish Parliament and local elections. In the latter case $84 \%(\mathrm{~N}=1189)$ of those who voted said that they found the process 'not very' or 'not at all' difficult - only a slightly smaller proportion than said the same of the Holyrood elections $(87.5 \%, \mathrm{~N}=1179)$.

Proponents of proportional representation frequently suggest that it gives voters a greater incentive to vote. Under first-past-the-post many votes are 'wasted' and the result in most electoral districts is a foregone conclusion. With PR, however, every vote counts (or, at least, more votes 'count') and this leads to a higher turnout. It is impossible to tell whether STV 
made a difference to turnout in the 2007 Scottish council elections, however. As already indicated, they coincided with the Scottish Parliament elections and the normal assumption is that it is factors associated with the latter - such as constituency marginality - that drive turnout patterns. Indeed, the SES post-election survey found that slightly more respondents (9\%) said that STV made them less likely to vote than said it made them more likely $(7 \%)$ with the rest saying that it made no difference.

For the record, Table 4 shows local election turnout in 1999, 2003 and 2007. Overall, turnout increased in 2007 to $53.8 \%$. The increase was doubtless due to the fact that the Scottish Parliament election was widely expected to be a close-run thing (as, indeed, proved to be the case).

Table 4

Turnout in Council Elections 1999-2007

$\begin{array}{cccc} & & & \text { Change } \\ 1999 & 2003 & 2007 & 2003-7 \\ \% & \% & \% & \\ 58.1 & 49.6 & 53.8 & +4.2\end{array}$

There was considerable variation in turnout across councils - from $44.3 \%$ in Glasgow (the only council below 50\%) to $64.7 \%$ in East Renfrewshire. The figure exceeded $60 \%$ in four councils. In part, these differences are by-products of differential turnout in the Scottish Parliament elections, but more generally they reflect the contextual variables which are regularly associated with variations in turnout, such as the socio-economic composition of the area concerned. These latter factors tend to make variations in turnout across local authorities relatively predictable and this is illustrated by the fact that the correlation coefficient measuring the strength of the association between turnout at the 2003 council elections and local turnout in 2007 across the 32 council areas was +0.825 . This indicates a very strong relationship - councils which had higher turnouts in 2003 also had higher turnouts in 2007; those where turnout was lower in 2003 were also towards the bottom end in 2007.

\section{The Voters: Patterns of Party Support}

Under STV there is no measure of party support that is as straightforward as share of votes under first-past-the-post. In other STV systems (Ireland, for example) the convention is to use first preference votes as indicators of party support and to aggregate the first preferences obtained by all candidates of a party within each electoral district in order to arrive at figures showing the distribution of party support. That is the procedure adopted here and Table 5 compares the distribution of party support in 2007 with the two previous sets of elections.

Table 5

Share of Votes in Council Elections 1999-2007

$\begin{array}{lcccc} & & & & \text { Change } \\ & 1999 & 2003 & 2007 & 2003-07 \\ \text { Con } & \% & \% & \% & \\ \text { Lab } & 13.7 & 15.2 & 15.6 & +0.4 \\ \text { Lib Dem } & 36.6 & 32.9 & 28.1 & -4.8 \\ & 12.7 & 14.6 & 12.7 & -1.9\end{array}$




$\begin{array}{lccrr}\text { SNP } & 28.9 & 24.3 & 27.9 & +3.6 \\ \text { Ind } & 6.5 & 9.5 & 10.9 & +1.4 \\ \text { SSP } & 0.9 & 3.4 & 0.9 & -2.5 \\ \text { Solid } & - & - & 0.9 & +0.9 \\ \text { Green } & & 0.0 & 2.2 & +2.3 \\ \text { Others } & 0.8 & 0.2 & 0.9 & +0.7\end{array}$

The level of Conservative support reached an all-time low in Scotland in the 1995 local elections (11.3\%) but since then the party has staged a mini-recovery, which by 2003 saw the Tories back above 15\% of the votes cast. In 2007 they inched further forward to $15.6 \%$ (although this was mainly because they contested a much larger proportion of wards than before). The Liberal Democrats, on the other hand, fell back to their 1999 level. The SNP had suffered a sharp setback in 2003, in what was a disappointing set of elections for the party. In 2007 they recovered somewhat but were still not as strong as they had been in 1999. To a large extent, however, this reflects the SNP policy of restricting the number of candidates that they put forward. In two-thirds of all wards (more than $70 \%$ excluding the islands) the SNP put forward just one candidate. This may have been an effective strategy in terms of winning seats but it may also have reduced the number of first preference votes received. Support for Independents increased slightly by this measure, most probably because of the increase in the number of Independent candidates.

Labour's vote share in 2003, at just under a third, represented the party's worst performance in Scottish local elections since 1977 (when they had 31.6\%) but in 2007 support fell well below that level to produce Labour's worst local showing since the local government structure was overhauled in 1974. It is doubtful whether this represents a judgement on the performance of Labour councils. Clearly, Labour at UK level was undergoing a period of unpopularity and the SNP was particularly resurgent in Scotland for reasons that had little to do with how effective or otherwise local councils and councillors were performing.

Conceivably, the introduction of STV could have made a significant difference to patterns of party support in the local elections. For example, there may have been some people who previously voted tactically in first-past-the-post wards but now would see no need to do so with a first preference vote. In fact, if we compare the distribution of support for the four major parties only (in order to control to some extent for variations in candidatures) in the local elections with the distribution in the first-past-the-post constituency contests for the Scottish Parliament the two are very similar. In addition the main pattern of change from 2003 in the local elections was similar to that in the Scottish Parliament elections; in both, the SNP clearly gained support while Labour fell back significantly and support for the other parties changed little. ${ }^{2}$ This suggests that if STV had any impact on voting patterns - at least as far as first preferences are concerned - then it was very marginal.

A similar conclusion follows from analysis of variations in party support across councils. Despite changes in the level of support for the parties from 2003 to 2007, the relative strength of the parties across authorities was very similar in both sets of elections. Correlating the parties' vote shares at council level in 2003 and 2007 (excluding the islands) gives the following coefficients:

$\begin{array}{ll}\text { Conservatives } & 0.927 \\ \text { Labour } & 0.972 \\ \text { Liberal Democrats } & 0.857 \\ \text { SNP } & 0.939\end{array}$


These indicate very strong relationships and show that - despite the introduction of a new electoral system - there was strong continuity in the geography of party support. Where a party did well under first-past-the-post in 2003, it also did well under STV in 2007.

At the level of individual voters, survey data show that a significant minority of voters chose different parties and/or candidates in the constituency and local contests. Of those who voted for a major party in the constituency contests, $72 \%$ gave the same party their first preference in the council election while $14 \%$ opted for a different major party and $9 \%$ for an Independent and $4 \%$ for a minor party $(\mathrm{N}=1095)$. It is doubtful, however, whether any different pattern would have been found if both sets of elections were conducted using firstpast-the-post. DAVID - DO YOU HAVE A REFERENCE FOR THIS?

\section{The Voters: 'Alphabetical' Voting}

In the aftermath of the elections there were complaints made (frequently by defeated councillors) that the STV system had favoured candidates placed near the top of the ballot paper (i.e. those with surnames starting with a letter towards the beginning of the alphabet). The proposition put forward was that voters wanting to vote for the candidates of a particular party tended to give their first preference to the candidate coming first on the ballot and subsequent preferences to those lower down. Evidence for this tendency is given in Table 6 . In wards in which a party had two candidates, the one whose name came first on the ballot received more first preferences in the great majority of cases ( $84.7 \%$ overall) than the candidate who was in a lower position in the ballot. In the relatively few cases in which a party had three candidates the pattern is a little more complex, but in most cases $(67.3 \%$ overall) the candidate coming earliest on the ballot received most first preferences. Since a random distribution would have yielded a figure close to $50 \%$ in the two-candidate case, and to $33 \%$ where there were three candidates, it is clear that being placed towards the top of the ballot paper was a significant advantage in terms of gaining first preference votes and hence in being elected. Whether this consequence of STV will lead to a review of how the system is implemented - with places on the ballot perhaps being determined by lot - or whether really keen candidates will change there name to something beginning with ' $\mathrm{A}$ ' remains to be seen.

Table 6

'Alphabetical' Voting in STV Wards

$\begin{array}{lccccc}\begin{array}{l}\text { Two Candidate Wards } \\ \text { Higher-placed candidate } \\ \text { most first preferences }\end{array} & \text { Con } & \text { Lab } & \text { LibDem } & \text { SNP } & \text { Total } \\ \begin{array}{l}\text { Lower-placed candidate } \\ \text { most first preferences }\end{array} & 7.7 & 14.0 & 24.1 & 15.4 & 84.7 \\ \begin{array}{l}\text { (N) } \\ \text { Three Candidate Wards }\end{array} & (39) & (143) & (54) & (91) & 15.3 \\ \begin{array}{l}\text { Highest-placed candidate } \\ \text { most first preferences }\end{array} & 75.0 & 64.9 & 66.7 & 80.0 & 67.3\end{array}$


Middle candidate

most first preferences

0.0

8.1

0.0

0.0

6.1

Lowest-placed candidate most first preferences

\section{The System: From Votes to Seats and Seats to Control of Councils}

When STV was introduced for council elections in Scotland it was widely expected that Labour would be the major loser and the SNP the main gainer. For that reason, the change was bitterly opposed by leading Labour figures in local government. As Table 7 indicates, in 1999 and 2003 Labour was by far the largest party in Scottish local government. However, Labour's share of seats in these elections $(45.1 \%$ and $41.7 \%$ respectively) far exceeded the party's vote share $(36.3 \%$ and $32.6 \%$ ) and the point of STV is to make the distribution of seats more proportional to voting support among the electorate. The consequence was that the number of seats won by Labour in 2007 fell by 160 while the SNP increased its representation by 184 seats. Although this is partly explained by the fact that the SNP was simply more popular in 2007 than it had been in 2003 and Labour less popular, there is little doubt that the main reason for it is the electoral system. The Conservatives also benefited from the introduction of the system - a very small increase in vote share yielded 20 additional seats - while the decline in popular support for the Liberal Democrats was reflected in a slight drop in number of seats won. STV did not usher in a golden era for minor parties or non-party candidates. The Green party would certainly not have won 8 seats under first-pastthe-post but that has to be balanced against a sharp decline in the number of Independents elected - to the smallest number ever - and the failure of the small left-wing parties to make any impact.

Table 7

Council Seats Won in Local Elections 1999-2007

$\begin{array}{lrrrr} & 1999 & 2003 & 2007 & \begin{array}{c}\text { Change } \\ 2003-07\end{array} \\ \text { Con } & 108 & 123 & 143 & +20 \\ \text { Lab } & 551 & 509 & 348 & -160 \\ \text { Lib Dem } & 156 & 175 & 166 & -9 \\ \text { SNP } & 204 & 181 & 363 & +182 \\ \text { Ind } & 191 & 231 & 187 & -44 \\ \text { SSP } & 1 & 2 & 1 & -1 \\ \text { Solid } & - & - & 1 & +1 \\ \text { Green } & 0 & 0 & 8 & +8 \\ \text { Others } & 11 & 1 & 5 & +4 \\ \text { Total } & 1,222 & 1,222 & 1,222 & \end{array}$

The effect of STV in translating vote preferences into seats was to make the relationship between the two more proportional. Table 8 shows the distribution of first preference votes and seats in 2007 as compared with votes and seats in 2003. Independents remain somewhat over-represented due to their strength in the islands councils (which have small electorates),m 
and 'others' under-represented, but STV substantially reduced the previous disparity between seats and votes for the major parties (especially in relation to Labour and the SNP). Overall, on the basis of the figures in Table 8 , the index of disproportionality (the sum of differences between $\%$ of seats and \% of votes divided by two) fell from 18.2 in 2003 to 7.5 in 2007.

Table 8

Council Elections: Votes and Seats 2003 and 2007

\begin{tabular}{lcccc} 
& \multicolumn{2}{c}{2003} & & \multicolumn{2}{c}{2007} \\
& Votes & Seats & Votes & Seats \\
Conservative & $\%$ & $\%$ & $\%$ & $\%$ \\
Labour & 15.2 & 10.1 & 15.6 & 11.7 \\
Liberal Democrat & 32.9 & 41.7 & 28.1 & 28.5 \\
SNP & 14.6 & 14.3 & 12.7 & 13.6 \\
Independent & 24.3 & 14.8 & 27.9 & 29.7 \\
Others & 9.5 & 18.9 & 10.9 & 15.3 \\
& 3.6 & 0.3 & 4.9 & 1.3
\end{tabular}

A knock-on effect of the more proportional distribution of seats was that many more incumbents (in particular Labour incumbents) were defeated than usual. When combined with the fact that fewer incumbents than usual chose to defend their seats (or were ousted in the selection of candidates) the net effect was a large turnover in the personnel sitting in council chambers. Whereas in $200376 \%$ of those who won council seats were already incumbents, in 2007 the figure was only $51 \%$. There was, then, a considerable infusion of new blood into Scottish local government in 2007, largely brought about by the introduction of STV.

Finally, the more proportional distribution of seats had major consequences for political control of councils, and hence for the conduct of local politics in Scotland. Table 9 illustrates the pattern of party control on the basis of the election results in 2007 as compared with the situation after the three previous sets of elections. Back in 1995, only three councils did not have a single party or group in overall control. The number increased in 1999 and 2003 as cracks appeared in the Labour monolith, but the impact of STV in 2007 is very clear. 'Hung' councils, with their attendant problems and opportunities, are now the norm. The only mainland councils with one party or group in control are Glasgow and North Lanarkshire (both Labour). Only the very small three islands councils have an overall majority of Independents. This is a major change. Previously most local authorities were run on the basis of 'party government'. The majority party would form the administration, taking all the leading council positions, while the remainder formed the opposition. Now in almost all councils there has to be either a minority administration or some form of coalition or sharing of power. A variety of ruling coalition arrangements have emerged. In a number of cases the administration comprises the Liberal Democrats and the SNP (Aberdeen, Edinburgh, Renfrew, for example) but elsewhere it is a coalition of Labour and the Liberal Democrats (Dundee and Stirling). In other cases there is a sort of rainbow coalition excluding only one party (Conservatives, Liberal Democrats and SNP in Dumfries and Galloway; Conservatives, Labour, Liberal Democrats and Independents in Angus). In at least one case (South Ayrshire) there appears to be a form of government without opposition as all parties seem to be represented in key positions.

Table 9 
Party Control of Councils 1995-2007

$1995 \quad 2003 \quad 2007$

$\begin{array}{lrrrr}\text { Conservative majority } & 0 & 0 & 0 & 0 \\ \text { Labour majority } & 20 & 15 & 13 & 2 \\ \text { Lib Dem majority } & 0 & 0 & 1 & 0 \\ \text { SNP majority } & 3 & 1 & 1 & 0 \\ \text { Ind majority } & 6 & 6 & 6 & 3 \\ \text { No Overall Control } & 3 & 10 & 11 & 27\end{array}$

\section{Conclusion}

The 2007 Scottish council elections dramatically redrew the political map of local government in Scotland. Ten years ago it would have been only a slight exaggeration to describe local government in the populous central belt could previously as a series of oneparty 'statelets'. Thanks to STV this is no longer the case and a return to Labour (or indeed any other party) domination on this scale seems most unlikely. In addition, as we have seen, the 2007 elections also produced major changes in the personnel sitting in the council chambers. It remains to be seen whether this quiet revolution will blow a breath of fresh air through the musty corridors of Scottish local government and increase the interest of electors in the policies and actions of their local councils and councillors. The introduction of STV may well be a step forward in this regard but the practice of holding council elections on the same day as Scottish Parliament elections seriously weakens local democracy. 'Decoupling' the two would increase interest in, and attention to, council elections and enable local voters more easily to hold their local representatives to account.

\section{Footnotes}

1. The Scottish Election Study was financed by the ESRC and involved pre- and postelection internet surveys of the electorate. The project is directed by Rob Johns, David Denver, James Mitchell and Charles Pattie.

2. The figures are:

$\begin{array}{lcccc} & \begin{array}{c}\text { Council } \\ \text { Elections } \\ \%\end{array} & \begin{array}{c}\text { Change } \\ 2003-07\end{array} & \begin{array}{c}\text { Constituency } \\ \text { Contests } \\ \%\end{array} & \begin{array}{c}\text { Change } \\ 2003-07\end{array} \\ \text { Con } & 18.5 & +1.0 & 17.0 & -1.4 \\ \text { Lab } & 33.4 & -4.4 & 32.9 & -5.4 \\ \text { LibDem } & 15.1 & -1.7 & 16.5 & -0.5 \\ \text { SNP } & 33.0 & +5.1 & 33.7 & +7.4\end{array}$

